\title{
Ichthyofauna of the rio Itatinga in the Parque das Neblinas, Bertioga, São Paulo State: composition and biogeography
}

\author{
Jane Piton Serra ${ }^{1}$, Fernando Rogério de Carvalho ${ }^{1}$ \& Francisco Langeani $^{1,2}$ \\ Biota Neotropica v7 (n1) - http://www.biotaneotropica.org.br/v7n1/pt/abstract?article +bn01707012007 \\ Data Received 12/10/05 \\ Revised 15/09/06 \\ Accepted 08/01/07 \\ ${ }^{1}$ Universidade Estadual Paulista - UNESP, Laboratório de Ictiologia, \\ Departamento de Zoologia e Botânica, Rua Cristóvão Colombo, 2265, \\ CEP 15054-000, São José do Rio Preto, SP, Brazil \\ ${ }^{2}$ Corresponding author: Francisco Langeani, e-mail: langeani@ibilce.unesp.br,www.ibilce.unesp.br
}

\begin{abstract}
Serra, J.P., Carvalho, F.R. \& Langeani, F. Ichthyofauna of the rio Itatinga in the Parque das Neblinas, Bertioga, São Paulo state: composition and biogeography. Biota Neotrop. Jan/Apr 2007 vol. 7, no. 1 http://www.biotaneotropica.org.br/v7n1/pt/abstract?article+bn01707012007 ISSN 1676-0603.

Little is known about the ichthyofauna from South American coastal plain, specially concerning the Mata Atlântica (Atlantic Forest) rivers and streams, as there are regions little explored which may have nondescribed or rare species. An example is the Parque das Neblinas, a Natural Patrimony Private Reserve (RPPN) in the Bertioga municipality, São Paulo state, where no ichthyofaunal study had been done before. The park's hydrography is made up by the rio Itatinga with its various tributary streams, which flow into the Itapanhaú river basin. Nine sites were sampled using sieves, seines and gill nets; 1,086 specimens of seven species, three orders and five families were captured. The most representative species were Astyanax paranae, Phalloceros caudimaculatus, and Coptobrycon bilineatus. Four of those collected are on the Brazilian list of endangered species: Coptobrycon bilineatus, Glandulocauda melanogenys, Pseudotocinclus tietensis, and Taunaya bifasciata; one, Trichomycterus sp., has an undefined taxonomic status, possibly being a non-described species. The richness of species found in the upper part of the rio Itatinga is typical of the Mata Atlântica headwaters, which can also be due to headwater capture of part of the upper rio Tietê. This is the first record of Coptobrycon bilineatus in the coastal drainage, hitherto restricted to the upper Paraná river system. The distribution of Taunaya bifasciata and Pseudotocinclus tietensis is also extended. The fauna sharing found here confirms the biogeographical common history hypothesis among southeastern coastal and Brazilian Shield drainages.

Keywords: endangered species, fauna sharing, conservation, coastal river, fauna inventory, southeastern Brazil.

\section{Resumo}

Serra, J.P., Carvalho, F.R. \& Langeani, F. Ictiofauna do rio Itatinga no Parque das Neblinas, Bertioga, Estado de São Paulo: composição e biogeografia. Biota Neotrop. Jan/Apr 2007 vol. 7, no. 1 http://www.biotaneotropica.org.br/v7n1/pt/abstract?article+bn01707012007 ISSN 1676-0603.

A ictiofauna da planície costeira do leste da América do Sul é pouco conhecida, especialmente em relação aos rios e riachos da Mata Atlântica, existindo regiões pouco exploradas, que podem abrigar espécies raras ou não descritas para a ciência. Exemplo dessa situação é o Parque das Neblinas, uma Reserva Particular do Patrimônio Natural (RPPN) no município de Bertioga, estado de São Paulo, onde nenhum levantamento ictiofaunístico havia sido feito até o presente. A hidrografia do Parque é formada pelo rio Itatinga e seus vários riachos afluentes, que deságuam na bacia do rio Itapanhaú. Foram amostrados nove pontos utilizando peneiras de arroz, redes de arrasto e redes de espera, que resultaram na captura de 1.086 exemplares de peixes, de sete espécies, três ordens e cinco famílias. As espécies mais representativas foram Astyanax paranae, Phalloceros caudimaculatus e Coptobrycon bilineatus. Quatro das espécies coletadas estão na lista de espécies brasileiras ameaçadas de extinção: Coptobrycon bilineatus, Glandulocauda melanogenys, Pseudotocinclus tietensis e Taunaya bifasciata. Uma das espécies, Trichomycterus sp., apresenta status taxonômico indefinido, podendo se tratar de uma espécie não descrita. A riqueza de espécies encontrada nessa porção do alto curso do rio Itatinga é típica de riachos de cabeceira de Mata Atlântica, podendo também ser conseqüência de fenômeno de captura de cabeceiras de porção do Alto rio Tietê. O encontro de Coptobrycon bilineatus consiste no primeiro registro para drenagens litorâneas, antes restrita ao sistema do Alto rio Paraná. Amplia-se também a distribuição de Taunaya bifasciata e Pseudotocinclus tietensis. O compartilhamento de fauna aqui apresentado corrobora a hipótese de história biogeográfica comum entre porções das drenagens costeiras do sudeste e do escudo brasileiro.
\end{abstract}

Palavras-chave: espécies ameaçadas, compartilhamento de fauna, conservação, rio litorâneo, inventário de fauna, sudeste do Brasil. 


\section{Introduction}

The Mata Atlântica fish fauna is distinguished by its rich variety and for having a high degree of endemicity and an intimate association with the forest; which principally guarantee protection and sustenance to the ichthyofauna (Sabino \& Castro 1990, Menezes 1996). The courses of water associated with the Mata Atlântica are generally of limited extension, therefore very vulnerable to environmental degradation (Buckup 1996). Because of the destruction of the forests, now down to 2 to $5 \%$ of their original extent, the fish fauna has been reduced to a small fraction of what it used to be (Menezes 1996), probably also causing extinction of unknown-to-science species.

Relatively little is known of the South American ichthyofauna, especially about fishes in the rivers and streams of the Mata Atlântica (Sazima et al. 2001, Buckup 1996, Sabino 1996), which represent poorly explored environments. According to Menezes (1996), to solve the lack of information about the ichthyofaunistic composition of the Mata Atlântica's rivers and streams, a great effort is needed to collect, catalogue and identify fishes, aiming to discover new or rare species. Besides this, information about the fish communities in coastal drainage regions is scarce and fragmented, which makes it difficult to adequately understand the historical processes, which shaped the fauna of freshwater fishes of the Brazilian coast (Bizerril \& Lima 2000).

The Parque das Neblinas hydrography is composed of the rio Itatinga, in the Itapanhaú river basin, with its various tributary streams which flow through the Bertioga canal to the Atlantic Ocean. The rio Itatinga borders all the east side of the Parque das Neblinas, demarcating it from the Serra do Mar State Park. This region is part of an area which shares a common biogeographical history with the upper Tietê and upper Paraíba do Sul river basins, thus being of great biogeographical interest and importance to understand the present species distribution processes in those areas. In this study we surveyed the ichthyofauna of the rio Itatinga in the Parque das Neblinas, and investigated its composition discussing aspects of the area biogeography.

\section{Materials and Methods}

\section{Study area}

The Parque das Neblinas is a Natural Patrimony Private Reserve (RPPN) belonging to the Companhia Suzano de Papel e Celulose (Suzano Paper and Cellulose Company) in the Bertioga municipality, São Paulo state (Figure 1). It is located on the crystalline escarpment of the Serra do Mar, in the Itatinga complex, defined by the occurrence of gneiss and migmatites on the southeast of the Freires cataclistic zone (Rideg 1974); between the low-heat tropical and mild mesothermal tropical climates, both without droughts (Nimer 1979). All of the park's area is covered by the Floresta Ombrófila Densa Atlântica, generically known as the Mata Atlântica, which includes a complex of vegetable formations and countless associations (Secretaria do Meio Ambiente 1996), at present with different degrees of anthropic disturbance, as by the presence of eucalypt trees (Eucalyptus spp.).

The study of the park's fishes was done as part of its management plan. Collecting efforts concentrated specially in the rio Itatinga due to access difficulty to other courses of water. Along its length, the rio Itatinga is made up of regions with fast rapids and others with calm waters, alternating deep and shallow stretches; the river bed is composed of sand and stones (from flint-stone to aconite and basalt flagstones); forest leaves, branches and trunks gather in the pools or lentic water regions; the water is cold (around $15{ }^{\circ} \mathrm{C}$ ) and transparency is total.

\section{Sampling}

Sampling was done during the daylight between the 26th and 29th of May, 2004, at nine sites (Figure 2). The equipment used was sieves ( $3 \mathrm{~mm}$ between knots), seines ( $2 \mathrm{~mm}$ between knots), and gill nets (20 $\mathrm{mm}$ between knots). Collections objectified just a qualitative analysis to the management plan for the Parque das Neblinas and because of that collecting effort was not standardized.

The collected specimens were immediately immersed in a $10 \%$ formaldehyde solution for fixation and transferred to $70 \%$ ethanol alcohol after 48 hours. The specimens are deposited in the fish collection (DZSJRP 6599 to 6632) of the Departamento de Zoologia e Botânica (Zoology and Botany Department) of the UNESP, Universidade Estadual Paulista, São José do Rio Preto, São Paulo.

\section{Results and Discussion}

\section{Ichthyofauna}

Seven fish species belonging to three orders and five families were registered (Figure 3 ), with a total of 1,086 specimens (Table 1). The most abundant and widely distributed species were Astyanax paranae, Phalloceros caudimaculatus, and Coptobrycon bilineatus. Of the

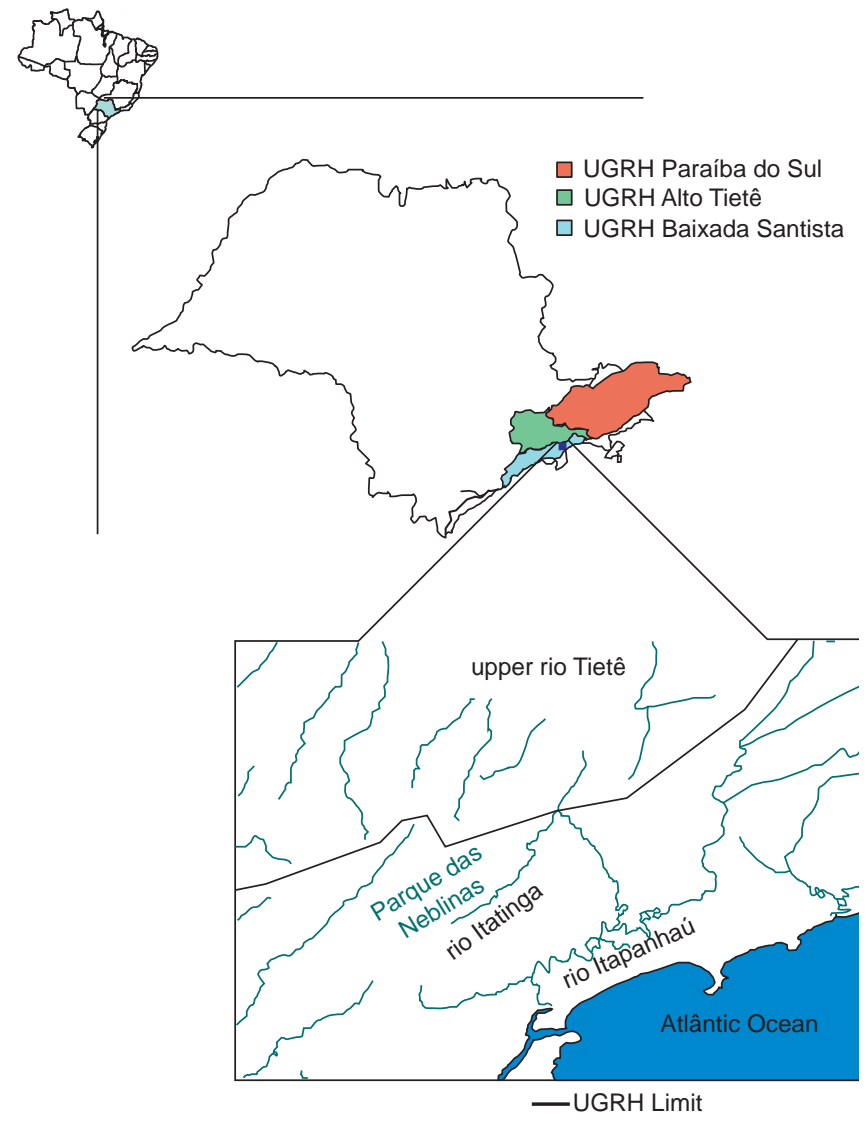

Figure 1. Geographic position of the rio Itatinga in the Parque das Neblinas, Bertioga municipality, São Paulo state, Brazil. UGRH refers to the hydric management unit for human use; dark line crossing drainages indicates limits between distinct UGRH.

Figura 1. Localização geográfica do rio Itatinga no Parque das Neblinas, município de Bertioga, estado de São Paulo, Brasil. UGRH refere-se à unidade de gerenciamento de recursos hídricos para uso humano; linha negra cruzando as drenagens indica os limites entre UGRHs distintas. 

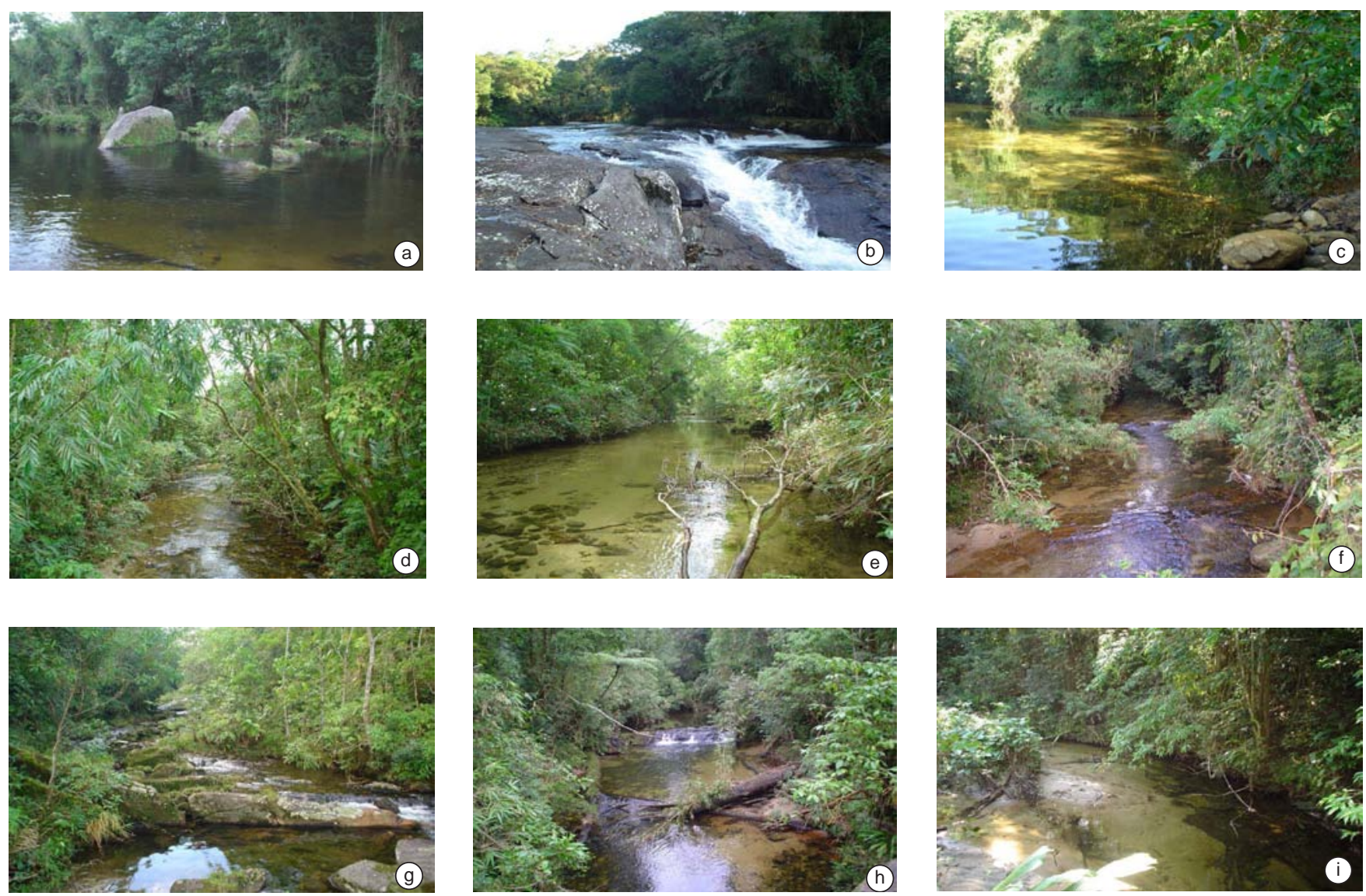

Figure 2. Sampled sites in the Rio Itatinga watershed, Parque das Neblinas. a) rio Itatinga ( $23^{\circ} 44^{\prime} \mathrm{S}$ and $\left.46^{\circ} 09^{\prime} \mathrm{W}\right)$; b) rio Itatinga ( $23^{\circ} 44^{\prime} \mathrm{S}$ and $46^{\circ} 09^{\prime} \mathrm{W}$ ); c) rio Itatinga ( $23^{\circ} 44^{\prime} \mathrm{S}$ and $\left.46^{\circ} 09^{\prime} \mathrm{W}\right)$; d) stream mouth in the right bank of rio Itatinga $\left(23^{\circ} 47^{\prime} \mathrm{S}\right.$ and $\left.46^{\circ} 12^{\prime} \mathrm{W}\right)$; e) rio Itatinga ( $23^{\circ} 47^{\prime} \mathrm{S}$ and $\left.46^{\circ} 12^{\prime} \mathrm{W}\right)$; f) stream mouth in the right bank of rio Itatinga ( $\left(23^{\circ} 47^{\prime} \mathrm{S}\right.$ and $\left.46^{\circ} 11^{\prime} \mathrm{W}\right)$; g) stream mouth in the right bank of rio Itatinga $\left(23^{\circ} 46^{\prime} \mathrm{S}\right.$ and $\left.46^{\circ} 10^{\prime} \mathrm{W}\right)$; $\left.\mathrm{h}\right)$ stream mouth in the right bank of rio Itatinga ( $23^{\circ} 46^{\prime} \mathrm{S}$ and $\left.46^{\circ} 10^{\prime} \mathrm{W}\right)$; and i) stream mouth in the right bank of rio Itatinga $\left(23^{\circ} 45^{\prime} \mathrm{S}\right.$ and $\left.46^{\circ} 09^{\prime} \mathrm{W}\right)$.

Figura 2. Pontos amostrados no rio Itatinga, Parque das Neblinas. a) rio Itatinga ( $23^{\circ} 44^{\prime} \mathrm{S}$ e $\left.46^{\circ} 09^{\prime} \mathrm{W}\right)$; b) rio Itatinga ( $23^{\circ} 44^{\prime} \mathrm{S}$ e $\left.46^{\circ} 09^{\prime} \mathrm{W}\right)$; c) rio Itatinga $\left(23^{\circ} 44^{\prime} \mathrm{S}\right.$ e $\left.46^{\circ} 09^{\prime} \mathrm{W}\right)$; d) desembocadura de riacho afluente da margem direita do rio Itatinga ( $23^{\circ} 47^{\prime} \mathrm{S}$ e $\left.46^{\circ} 12^{\prime} \mathrm{W}\right)$; e) rio Itatinga ( $23^{\circ} 47^{\prime} \mathrm{S}$ e $46^{\circ} 12^{\prime} \mathrm{W}$ ); f) desembocadura de riacho afluente da margem direita do rio Itatinga $\left(23^{\circ} 47^{\prime} \mathrm{S}\right.$ e $\left.46^{\circ} 11^{\prime} \mathrm{W}\right)$; g) desembocadura de riacho afluente da margem direita do rio Itatinga ( $23^{\circ} 46^{\prime} \mathrm{S}$ e $\left.46^{\circ} 10^{\prime} \mathrm{W}\right)$; h) desembocadura de riacho afluente da margem direita do rio Itatinga $\left(23^{\circ} 46^{\prime} \mathrm{S}\right.$ e $\left.46^{\circ} 10^{\prime} \mathrm{W}\right)$; i) desembocadura de riacho afluente da margem direita do rio Itatinga $\left(23^{\circ} 45^{\prime} \mathrm{S}\right.$ e $\left.46^{\circ} 09^{\prime} \mathrm{W}\right)$.

Table 1. Abundance of fish species according to the collecting sites in the Parque das Neblinas, Bertioga municipality, São Paulo state, Brazil.

Tabela 1. Abundância das espécies de peixes em cada um dos pontos amostrados no Parque das Neblinas, município de Bertioga, estado de São Paulo, Brasil.

\begin{tabular}{|c|c|c|c|c|c|c|c|c|c|c|}
\hline \multirow[t]{2}{*}{ Taxon } & \multicolumn{9}{|c|}{ Collecting sites } & \multirow[t]{2}{*}{ Total } \\
\hline & 1 & 2 & 3 & 4 & 5 & 6 & 7 & 8 & 9 & \\
\hline \multicolumn{11}{|l|}{ Order Characiformes Family Characidae } \\
\hline Astyanax paranae Eigenmann, 1914 & 59 & & 31 & 5 & 18 & 69 & 17 & 207 & 1 & 407 \\
\hline Coptobrycon bilineatus (Ellis, 1911) & 5 & & 162 & & 13 & 103 & 1 & 3 & 10 & 297 \\
\hline \multicolumn{11}{|l|}{ Subfamily Glandulocaudinae } \\
\hline Glandulocauda melanogenys Eigenmann, 1911 & & & & 2 & & & & & & 2 \\
\hline \multicolumn{11}{|l|}{ Order Siluriformes Family Loricariidae } \\
\hline \multicolumn{11}{|l|}{ Subfamily Hypoptopomatinae } \\
\hline Pseudotocinclus tietensis (Ihering, 1907) & 1 & & 3 & & & & & 1 & & 5 \\
\hline \multicolumn{11}{|l|}{ Family Trichomycteridae } \\
\hline Trichomycterus sp. & 7 & & 27 & & & & & & & 34 \\
\hline \multicolumn{11}{|l|}{ Family Heptapteridae } \\
\hline Taunaya bifasciata (Eigenmann \& Norris, 1900) & & & & & 2 & 1 & 1 & & & 4 \\
\hline \multicolumn{11}{|l|}{ Order Cyprinodontiformes Family Poeciliidae } \\
\hline Phalloceros caudimaculatus (Hensel, 1868) & 90 & 39 & 52 & 9 & 34 & 41 & 24 & 12 & 36 & 337 \\
\hline
\end{tabular}



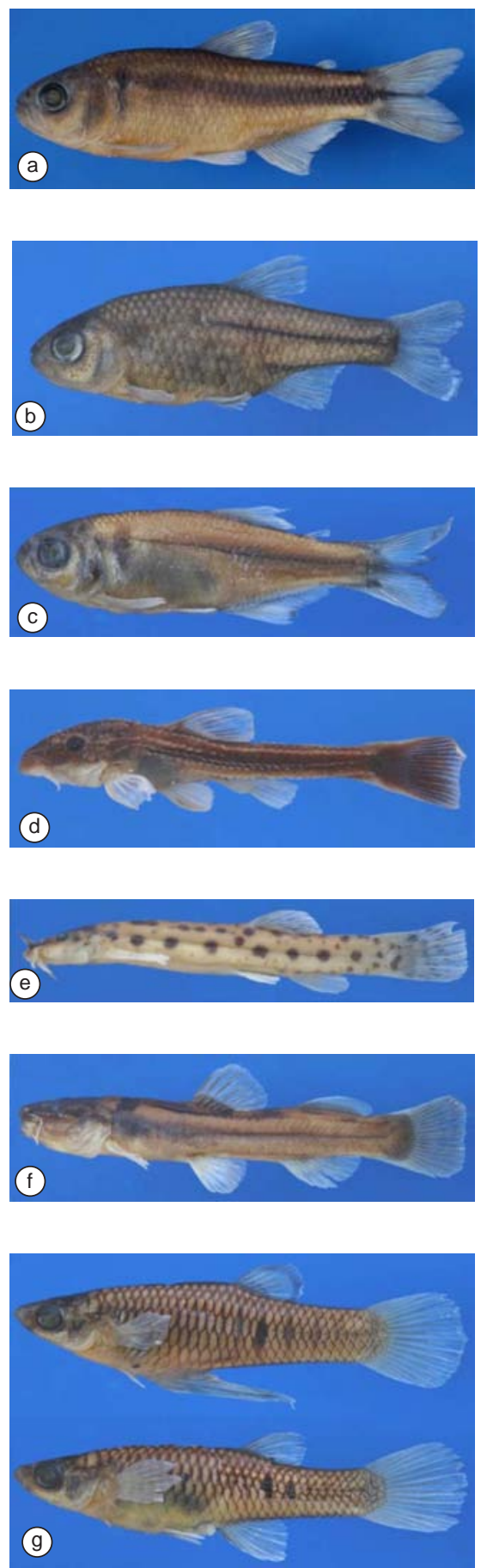

Figure 3. Fish species from the Rio Itatinga watershed, Parque das Neblinas: a) Astyanax paranae, DZSJRP 6629, $61.4 \mathrm{~mm} \mathrm{SL}$; b) Coptobrycon bilineatus, DZSJRP 6621, $31.6 \mathrm{~mm}$ SL; c) Glandulocauda melanogenys, DZSJRP 6613, 28.8 mm SL; d) Pseudotocinclus tietensis, DZSJRP 6599, $20.8 \mathrm{~mm}$; e) Trichomycterus sp., DZSJRP 6600, $30.8 \mathrm{~mm}$; f) Taunaya bifasciata, DZSJRP 6622, $42.9 \mathrm{~mm}$ SL; and g) Phalloceros caudimaculatus, DZSJRP 6607, male $28.8 \mathrm{~mm}$ (above), female $29.6 \mathrm{~mm}$ (below).

Figura 3. Espécies de peixes do rio Itatinga, Parque das Neblinas: a) Astyanax paranae, DZSJRP 6629, $61.4 \mathrm{~mm}$ CP; b) Coptobrycon bilineatus, DZSJRP 6621, $31.6 \mathrm{~mm}$ CPL; c) Glandulocauda melanogenys, DZSJRP 6613, $28.8 \mathrm{~mm} \mathrm{CP}$; d) Pseudotocinclus tietensis, DZSJRP 6599, $20.8 \mathrm{~mm} \mathrm{CP}$; e) Trichomycterus sp., DZSJRP 6600, $30.8 \mathrm{~mm}$ CP; f) Taunaya bifasciata, DZSJRP 6622, $42.9 \mathrm{~mm}$ CP; g) Phalloceros caudimaculatus, DZSJRP 6607, macho 28.8 mm CP (acima), fêmea 29.6 mm CP (abaixo). seven species collected, four are on the Brazilian Endangered Species List (Machado et al. 2005): Coptobrycon bilineatus, Glandulocauda melanogenys, Pseudotocinclus tietensis, and Taunaya bifasciata. Trichomycterus sp. has undefined taxonomic status, possibly being an undescribed species.

The richness of species found in the rio Itatinga are equivalent to other stretches of the southeastern Mata Atlântica streams; this confirms the expected pattern of hydrographic basin headwaters (Lowe-McConnell 1987); these streams normally have poor diversity and ichthyofauna is mainly dependant on allochthonous foods (Castro 1999). Similar richness such as that found in the rio Itatinga, as in streams both altered and unaltered by anthropic action, also occur in other Mata Atlântica streams of the upper rio Tietê, in forest coastal rivers and in tributaries of the rio Ribeira de Iguape, respectively with one to eight species (F. Langeani, pers. obs.), eight species (Sabino \& Castro 1990) and six to ten species (F.R. Carvalho, pers. obs.). For larger portions of these drainage regions, 42 species were referred to for the entire upper Tietê (Langeani 1989), 28 species for stretches of the upper rio Tietê and two of its tributaries, Paraitinga and Biritiba Mirim rivers (Silva et al. 2005) and 30 species for the rio Saibadela, in the Ribeira de Iguape drainage (Sazima et al. 2001).

Notwithstanding what has been expounded, it must also be considered that the richness of species found in the rio Itatinga may be a consequence of more recent historical events, related to the exploration of surrounding areas, notably those which now make up the Parque das Neblinas. The exploration of the park's forest for coal started in the 1940 decade, later this area was used to plant eucalypt trees (Eucaliptus spp.), also to produce coal, and then in the 1960 decade with the Suzano Paper and Cellulose Company to produce paper. This exploration was responsible for the removal of large parts of native forest, which could also have negatively influenced the richness of rio Itatinga fishes. Riparian vegetation has been considered extremely important to maintain the richness of species in Mata Atlântica streams (Castro 1999) and various authors register the fact that the small number of species may be due to degradation of that vegetation (Sazima et al. 2001, Menezes 1996, Buckup 1996, Sabino 1996). Removal of that vegetation can lead to a silting up of the rivers, a reduction of the number of micro-habitats and the increase of insolation on the courses of water, raising water temperature and harming sensitive species (Sabino 1996, Sabino \& Silva 2004); besides this, many fish depend partly or wholly on allochthonous foods, such as leaves, fruits and terrestrial arthropods, just as on aquatic larvae and insects that feed on that allochthonous organic matter (Sabino \& Castro 1990, Castro \& Casatti 1997). Nevertheless, richness of species comparisons based solely on environmental conservation must be done cautiously, since conditions in each river are not always equal, as with anthropic altered streams which have a more diverse stock of species than unaltered ones (cf. Ward \& Stanford 1983, for the intermediate disturbance hypothesis).

At present the Parque das Neblinas forest is in a continuous stage of recovery, having various areas excluded from the productive sector since the end of the 1970-decade, with the last area being explored in 2000. The presence of species such as Coptobrycon bilineatus and Glandulocauda melanogenys, rarely found today in the upper rio Tietê streams, shows the positive response of the ichthyofauna to the regeneration, mainly with the former which is abundant in the sampled sites. Despite this positive fact, Harding et al. (1998) maintain that vegetation removal limits recovery of aquatic diversity for many decades. Yet it is important to note that there is no data about the composition of rio Itatinga fishes before the surrounding forest was explored, which makes us unable to evaluate with any precision the real impact that exploration caused on the fish fauna. 


\section{Biogeography}

On the sampled stretch of the rio Itatinga, there is a plateau on the Jurubatuba tectonic block (Rideg 1974) between the Cubatão fault on the north and the Freires fault southeast (Almeida \& Carneiro 1998); it is separated from the rest of the Itatinga basin, on the coastal plain, by the Serra do Mar $700 \mathrm{~m}$ high escarpments and the Tietê river drainage, on the Paulistano plateau, by 200 to $300 \mathrm{~m}$ high crests (Almeida \& Carneiro 1998).

Four of the species collected from the rio Itatinga are of a fairly restricted geographic distribution: Coptobrycon bilineatus, Glandulocauda melanogenys, Pseudotocinclus tietensis, and Taunaya bifasciata. This is the first record of Coptobrycon bilineatus in the coastal drainage, previously considered endemic to the upper course of the rio Tietê (Langeani 1989, Lima et al. 2003). Furthermore, the distribution of Taunaya bifasciata is widened, previously only registered in the upper portions of Tietê and Paraíba do Sul rivers (Langeani 1989, Oliveira \& Britski 2000, Bockmann \& Guazzelli 2003) and also Pseudotocinclus tietensis, previously only registered in the upper Tietê and Ribeira de Iguape (respectively by Schaefer 2003 and Bizerril \& Lima 2000).

The partaking of fauna among coastal rivers (including Paraíba do Sul and Ribeira de Iguape) and headwaters of the Iguaçu, Paranapanema and Tietê rivers has been reported by various authors (Weitzman et al. 1988, Langeani 1989, Wosiacki \& Cury 1990, Bizerril 1994, Bizerril \& Lima 2000, Oliveira \& Britski 2000, Quevedo \& Reis 2002, Oyakawa et al. 2005, Ribeiro et al. 2006), who present Astyanax paranae, Characidium oiticicai, Corydoras eharhrdti, Glandulocauda melanogenys, Gymnotus pantherinus, Hollandichthys multifasciatus, Hyphessobrycon bifasciatus, Hyphessobrycon reticulatus, Hypostomus ancistroides, Imparfinis piperatus, Mimagoniates microlepis, Phallothothynus fasciolatus, Pseudocorynopoma heterandria, Pseudotocinclus tietensis, Taunaya bifasciata, and Trichomycterus davisi as being common between the Brazilian Shield and the coastal drainage regions. To this list is now added Coptobrycon bilineatus.

The common biogeographical history hypothesis for parts of these drainage regions was first registered by Menezes (1972) who, because of faunal similarities, mentioned the possibility that the principal EastBrazilian coastal rivers had inherited a large part of their ichthyofauna from the Paraná river basin, without, however, registering which were those common species. The upper Tietê and upper Paraíba do Sul rivers used to make up a pretermitted drainage which ran towards the Atlantic Ocean but, due to geological/geomorphological processes in the Serra do Mar region, this drainage was divided, one portion today corresponding to the upper rio Tietê and the other to the upper course of the rio Paraíba do Sul (Ab'Saber 1957). Langeani (1989) comments on this possibility based on ichthyofaunal composition of the upper Tietê, but points out the lack of ichthyofauna composition data from the upper Paraíba do Sul and other adjacent drainages to the upper Tietê, important to reinforce this hypothesis. Oliveira \& Britski (2000), in turn, register the presence of Taunaya bifasciata in the upper portions of Tietê and Paraíba do Sul, and also say that recent collections on the rio Paraíba do Sul showed various elements previously considered endemic of the Tietê headwaters, without, however, mentioning which taxa these may be. Bizerril \& Lima (2000) already registered the presence of species common to the Ribeira de Iguape, Iguaçu and Tietê rivers, hypothesizing past connections between these drainages.

That part of the southeastern Brazilian region, which includes various headwaters (Doce, Grande, Paraíba do Sul, Paranaíba, minor coastal rivers, São Francisco, and Tietê), is a geologically complex area due to tectonic activities in a very old rocky megadome during the Tertiary and probably the Quaternary; those tectonic activities were responsible for diverse headwater capture events (Ab'Saber 2003), like those which happened between the upper Tietê and the upper Paraíba do Sul river. Weitzman et al. (1988) suggest similar events between the rio Iguaçu and coastal drainages to explain the presence of Mimagoniates microlepis in the rio Iguaçu. Our results in the rio Itatinga seem to indicate that such processes also happened between the upper Tietê and other coastal rivers, as already demonstrated for portions of the Guaratuba and Tietê rivers by Ribeiro et al. (2006). The similarity of headwater fauna in that part of the Brazilian south and southeast reinforces Costa's (2001) hypothesis that there is a wider relationship between neighboring drainage headwaters than those drainages with the rest of its drainage basins.

\section{Final considerations}

The results presented here suggest the importance of a riparian forest to maintain the environmental integrity of native communities, principally for those components of the community which could be rapidly affected by the removal of the forest, notably due to influences on food, micro-habitats, and reproduction sites availability, as well as increasing water insolation, temperature, turbidity, and siltation (Ross 1997). The habitat changes occurred in various portions of the Mata Atlântica have probably been the reason for the disappearance of various endemic species which are now rarely found or completely absent in their original distribution areas, such as characids Coptobrycon bilineatus, Glandulocauda melanogenys, Glandulocauda melanopleura, Hasemania maxillaris, Hasemania melanura, Hyphessobrycon duragenys, Hyphessobrycon taurocephalus, Spintherobolus papilliferus. According to Sazima et al. (2001), studies followed by efficient preservation measures are necessary to avoid loss of fish species.

Creating preservation units for the Mata Atlântica rivers and streams (and its tributaries) is one of the few preservation alternatives for at least a portion of the fish fauna (Sazima et al. 2001, Sabino 1996). Transparent rivers and streams, like the rio Itatinga of the RPPN Parque das Neblinas, are favorable to underwater studies, especially as a tool to obtain data on feeding strategies, reproduction and relationships with other aquatic organisms (Sabino \& Castro 1990, Sabino 1996, Sabino 1999). Mid and long term studies about the fish community in the rio Itatinga are also of great interest, as they may make it possible to analyze the ichthyofauna's response to forest regeneration. Preserving the rio Itatinga and its tributary streams, as well as recovering riparian and surrounding forest, will guarantee the continuation of the existing ichthyofauna.

\section{Acknowledgments}

Henrique Figueira Chaves (Master student of the Programa de Pós-Graduação em Biologia Animal at UNESP, SJRP) helped with the collections; the Instituto de Pesquisas Ecológicas (IPE) and the Instituto Ecofuturo gave financial support and lodging; Fundação de Amparo à Pesquisa do Estado de São Paulo, Fapesp (grant 04/00545-8 to FL), Conselho Nacional de Desenvolvimento Científico e Tecnológico, CNPq (Doctoral scollarship to JPS), and Coordenação de Aperfeiçoamento de Pessoal de Nível Superior, Capes (MSc scollarship to FRC) also provided financial support; Alexandre C. Ribeiro (USP, Ribeirão Preto), Lilian Casatti (UNESP, SJRP), and two anonymous reviewers made valuable suggestions to improve the manuscript.

\section{References}

ALMEIDA, F.F.M. \& CARNEIRO, C.D.R. 1998. Origem e evolução da Serra do Mar. Rev. bras. Geociências, 28:135-150.

AB' SABER, N.A. 1957. O problema das conexões antigas e da separação da drenagem do Paraíba e Tietê. Bol. Paul. Geogr. 26:38-49. 
AB' SABER, N.A. 2003. Megamorfologia do território brasileiro. In Geomorfologia do Brasil (S.B. Cunha \& A.J.T. Guerra, eds). Bertand Brasil, $3^{\mathrm{a}}$. ed. Rio de Janeiro, p.71-106.

BIZERRIL, C.R.S.F.A. 1994. Análise Taxonômica e Biogeográfica da ictiofauna de água doce do leste brasileiro. Acta Biol. Leopoldensia, 16:51-80.

BIZERRIL, C.R.S.F.A. \& LIMA, N.R.M. 2000. Levantamento da ictiofauna da bacia do rio Ribeira de Iguape, Brasil. Acta Biol. Leopoldensia, 22:103-110.

BOCKMANN, F.A. \& GUAZZELLI, G.M. 2003. Heptapteridae. In Check List of Freshwater Fishes of South and Central America (CLOFFSCA) (R.E. Reis, S.O. Kullander \& C.J. Ferraris-Jr, orgs). Edipucrs, $1^{\text {a }}$ ed., Porto Alegre, p.406-431.

BUCKUP, P.A. 1996. Biodiversidade dos Peixes da Mata Atlântica. In Workshop Padrões de Biodiversidade da Mata Atlântica do Sudeste e Sul do Brasil. Campinas. (http://www.bdt.org.br, 05.vi.2004).

CASTRO, R.M.C. 1999. Evolução da ictiofauna de riachos sul-americanos: padrões gerais e possíveis processos causais. In Ecologia de Peixes de Riachos (E.P. Caramaschi, R. Mazzoni \& P.R. Peres-Neto, eds). Programa de Pós-Graduação em Ecologia, Instituto de Biologia, Universidade Federal do rio de Janeiro, rio de Janeiro, p.139-155.

CASTRO, R.M.C. \& CASATTI, L. 1997. The fish fauna from a small forest stream of upper Paraná River basin, southeastern Brazil. Ichthyol. Explor. Freshwaters, 7:337-352.

COSTA, W.J.E.M. 2001. The Neotropical annual fish genus Cynolebias (Cyprinodontiformes: Rivulidae): phylogenetic relationships, taxonomic revision and biogeography. Ichthyol. Explor. Freshwaters, 12:333-383.

HARDING, J.S., BENFIELD, E.F., BOLSTAD, P.V., HELFMAN, G.S. \& JONES, E.B.D. 1998. Stream biodiversity: The ghost of land use past. Proc. Natl. Acad. Sci. 95:14843-14847.

LANGEANI, F. 1989. Ictiofauna do Alto Curso do rio Tietê (SP): Taxonomia. Dissertação de mestrado, Universidade de São Paulo, São Paulo.

LIMA, F.C., MALABARBA, L.R., BUCKUP, P.A., SILVA, J.F.P., VARI, R.P., HAROLD, A., BENINE, R., OYAKAWA, O., PAVANELLI, C.S. MENEZES, N.A., LUCENA, C.A.S., MALABARBA, M.C.S.L., LUCENA, Z.M.S., REIS, R.E., LANGEANI, F., CASATTI, L., BERTACO, V.A., MOREIRA, C. \& LUCINDA, P.H.F. 2003. Characidae. In Check List of Freshwater Fishes of South and Central America (CLOFFSCA) (R.E. Reis, S.O. Kullander \& C.J. Ferraris-Jr, orgs). Edipucrs, $1^{\text {a }}$ ed., Porto Alegre, p.106-169.

LOWE-McCONNELL, R.H. 1987. Ecological Studies in Tropical Fish Communities. Cambridge University Press, Cambridge, NY.

MACHADO, A.B.M., MARTINS, C.S. \& DRUMOND, G.M. 2005. Lista da fauna brasileira ameaçada de extinção, incluindo as listas das espécies quase ameaçadas e deficientes em dados. Fundação Biodiversitas, Belo Horizonte, MG.

MENEZES, N.A. 1972. Distribuição e origem da fauna de peixes de água doce das grandes bacias fluviais do Brasil. In Comissão Internacional da Bacia Paraná/Uruguai. Poluição e Piscicultura, Faculdade e Saúde Pública da USP e Instituto de Pesca, São Paulo, p.79-108.

MENEZES, N.A. 1996. Padrões de distribuição da biodiversidade da Mata Atlântica do sul e sudeste brasileiro: peixes de água doce. In Workshop Padrões de Biodiversidade da Mata Atlântica do Sudeste e Sul do Brasil, Campinas. (http://www.bdt.org.br, 15.vi.2004).

NIMER, E. 1979. Climatologia do Brasil. IBGE, Rio de Janeiro, RJ.

OLIVEIRA, J.C. \& BRITSKI, H.A. 2000. Redescrição de Taunaya bifasciata (Eigenmann \& Norris, 1900), Comb. Nova, um Bagre Enigmático do Estado de São Paulo (Siluriformes, Pimelodidae, Heptapterinae). Pap. Avulsos Zool., São Paulo, 41:119-133.

OYAKAWA, O.T., AKAMA, A. \& ZANATA, A.M. 2005. Review of the genus Hypostomus Lacépède, 1803 from Ribeira de Iguape basin, with descriptions of a new species (Pisces, Siluriformes, Loricariidae). Zootaxa, 921:1-27.

QUEVEDO, R. \& REIS, R.E. 2002. Pogonopoma obscurum: a new species of loricariid catfish (Siluriformes: Loricariidae) from southern Brazil, with comments on the genus Pogonopoma. Copeia, 2002:402-410.

RIBEIRO, A.C., LIMA, F.C.T., RICCOMINI, C. \& MENEZES, N.A. 2006. Fishes of the Atlantic rainforest of Boracéia: tetimonies of the Quaternary fault reactivation within a Neoproterozoic tectonic province in Southeastern Brazil. Ichthyol. Explor. Freshwaters, 17:157-164.
RIDEG, P. 1974. Tectonics of the Serra do Mar between Mogi das Cruzes and Bertioga (SP) related to the separation of the continents. Anais do XXVIII Congr. Bras. Geologia, 6:225-239.

ROSS, M.R. 1997. Fisheries conservation and management. Prentice Hall, Upper Saddle River, NJ, 374 p.

SABINO, J. 1996. Peixes de riachos da Floresta Atlântica: introdução à ecologia e conservação. In Workshop Padrões de Biodiversidade da Mata Atlântica do Sudeste e Sul do Brasil, Campinas. (http://www.bdt.org.br, 15.vi.2004).

SABINO, J. 1999. Comportamento de peixes de riachos: métodos para uma abordagem naturalística. In: Ecologia de Peixes de Riachos. Caramaschi, E.P.; R. Mazzoni \& P.R. Perez-Neto (eds.). Série Oecologia Brasiliensis, volume VI. UFRJ, Rio de Janeiro, p.183-208.

SABINO, J. \& CASTRO, R.M.C. 1990. Alimentação, período de atividade e distribuição espacial dos peixes de um riacho da Floresta Atlântica (Sudeste do Brasil). Rev. bras. Biol. 50:23-36.

SABINO, J. \& SILVA, C.P.D 2004. História Natural de Peixes da Estação Ecológica Juréia-Itatins. In: Estação Ecológica Juréia-Itatins: Ambiente, flora e fauna. O.A.V. Marques \& W. Duleba (eds.). Holos Editora. Ribeirão Preto, São Paulo, p.230-242.

SAZIMA, I.; BUCK, S. \& SABINO, J. 2001. Peixes de riacho. In Intervales, Fundação para a Conservação e a Produção Florestal do Estado de São Paulo. Governo do Estado de São Paulo/Secretaria de Estado do Meio Ambiente, p.169-179.

SCHAEFER, S.A. 2003. Hypoptopomatinae. In Check List of Freshwater Fishes of South and Central America (CLOFFSCA) (R.E. Reis, S.O. Kullander \& C.J. Ferraris-Jr, orgs). Edipucrs, $1^{\mathrm{a}}$ ed., Porto Alegre, p.321-329.

SECRETARIA DO MEIO AMBIENTE. 1996. Macrozoneamento do litoral norte: plano de gerenciamento costeiro. Secretaria do Meio Ambiente, São Paulo, SP.

SILVA, F.S.D., MANNA-DE-DEUS, J.R. \& HILSDORF, A.W.S. 2005. The upper reached ichthyofauna of the Tietê River, São Paulo, Brazil: aspects of their diversity and conservation. Biodiv. Cons. (http://springerlink. metapress.com/media/99EQAMXQXL1KRXNXUQ7P/Contributions/ M/0/8/4/M084RU340H563936.pdf 26.viii.2005)

WARD, J.V. \& STANFORD, J.A. 1983. The intermediate-disturbance hypothesis: an explanation for biotic diversity patterns in lotic ecosystems. In Dinamics of lotic ecosystems (T.D. Fontaine III \& S.M. Bartell, eds.). Ann Arbour Sci., Ann Arbour, MI, p.347-356.

WEITZMAN, S.H., MENEZES, N.A. \& WEITZMAN, M.J. 1988. Phylogenetic biogeography of glandulocaudini (Teleostei: Characiformes, Characidae) with comments on the distribution off other freshwater fishes in eastern and southeastern Brazil. In Proceedings of a Workshop on Neotropical Distribution Patterns (W.R. Heyer \& P.E. Vanzolini, eds). Acad. Bras. Ciênc., Rio de Janeiro, p.379-427.

WOSIACKI, W.B. \& CURY, M.R. 1990. Inventário preliminar da ictiofauna da área especial de interesse turístico do Marumbi (Paraná), com comentários ictiogeográficos. Arq. Biol. Tecnol., 33:379-392.

Title: Ichthyofauna of the rio Itatinga in the Parque das Neblinas, Bertioga, São Paulo State: composition and biogeography.

Author: Serra, JP, Carvalho, FR e Langeani, F

Biota Neotropica, Vol.7 (number 1): 2007

http://www.biotaneotropica.org.br/v7n1/pt/abstract?article+ bn01707012007

Data Received 12/10/05 - Revised 15/09/06 Accepted 08/01/07

ISSN 1676-0603 